\title{
Extraction Approaches of Natural Dyes for Textile Coloration
}

\author{
Hany M. Helmy* \\ Textile Research Division, National Research Centre, Cairo, Egypt.
}

\begin{abstract}
$\mathbf{P}$ New techniques of extraction of natural dyes such as ultrasonic extraction, microwave extraction and utilization of enzyme are these days broadly being investigated for their high effectiveness over the traditional techniques. Ultrasonic or microwave techniques succeeded in accelerating the rate of, extraction at lower temperatures rather than the conventional heating technique. Ultrasonic power or microwave represents promising techniques for assisting extraction processes in comparison with the conventional heating technique. As plant tissues include cellulose, starches, and pectins, economically accessible enzymes such as; cellulase, amylase, and pectinase have been utilized to release the surrounded material prompting to the extraction of colourant particles in reasonable terms. Utilization of ultrasonic and enzyme for textile treatment additionally been examined and it has been announced that consolidated ultrasound and enzyme treatment augmented extraction yield marginally, however it reduced the time and temperature of treatment.
\end{abstract}

Keywords: Natural colourants, Enzymatic extraction, Ultrasonic and Microwave extraction, Dyeing methods

\section{Introduction}

The craft of colouration is as old as our development. Coloured materials residue discovered throughout antiquarian excavations at various venues everywhere the universe give confirmation of the act of colouring in old civilizations [1, 2]. Natural colourants were utilized mainly for textile colouration since very old time[3]. Natural coloured matters gotten from natural assets of animals, plants, minerals, and microbial sources were utilized for colouring of different kinds of textiles [4-7]. Various districts in the universe possess their own natural colouration conventionalisms using those natural assets accessible in that district $[8,9]$. Utilizing natural colouring substances started to decline after the revelation of man-made dyes toward the last period of 19 century. Intensive study exertions in the area of synthetic dyestuffs and quick manufacturing of textile processing brought about almost full surrogate of natural colourants (Fig.1) by synthetic dyestuffs because of their simple possibility in ready-to-apply form, easy application procedure, regularity of colours, and good fastness properties. That convention for utilizing natural colourants might survive just on definite isolated pockets.
Recent ecological knowledge needs once more restored enthusiasm toward natural colourants mostly around naturally aware individuals $[10$, 11]. Natural colourants are viewed as eco-friendly likewise these need aid renewable what's more biodegradable; are skin friendly and might be useful for the health of the wearer [12]. Natural colourants might make utilized for colouring most kinds of natural fibers [13-16]. Later exploration demonstrates that they could additionally make used to colour most of synthetic fibers. What's more numerous of the dye-yielding plants need aid utilized likewise medicines to Different universal medicinal frameworks. There are many challenges and restrictions connected with the utilization of natural colourants [17, 18]. Those present colourants requirement from that business may be over 3 million tons. In view of this fact, the utilization of natural colourants in conventional textile processes will be a huge challenge. Concerning cultivated land is principally desired for feeding an ever-increasing globe number. Furthermore help animals What's more biodiversity ought not a chance to be compromised to the extraction of colourants, sustainability of natural colourants may be a real issue $[4,19]$.

*Corresponding author: Hany M. Helmy, E mail: hany_helmy2001@yahoo.com

(Received 25/05/2020, accepted 14/06/2020)

DOI: $10.21608 /$ jtcps.2020.30990.1037

(C)2020 National Information and Documentation Centre (NIDOC) 


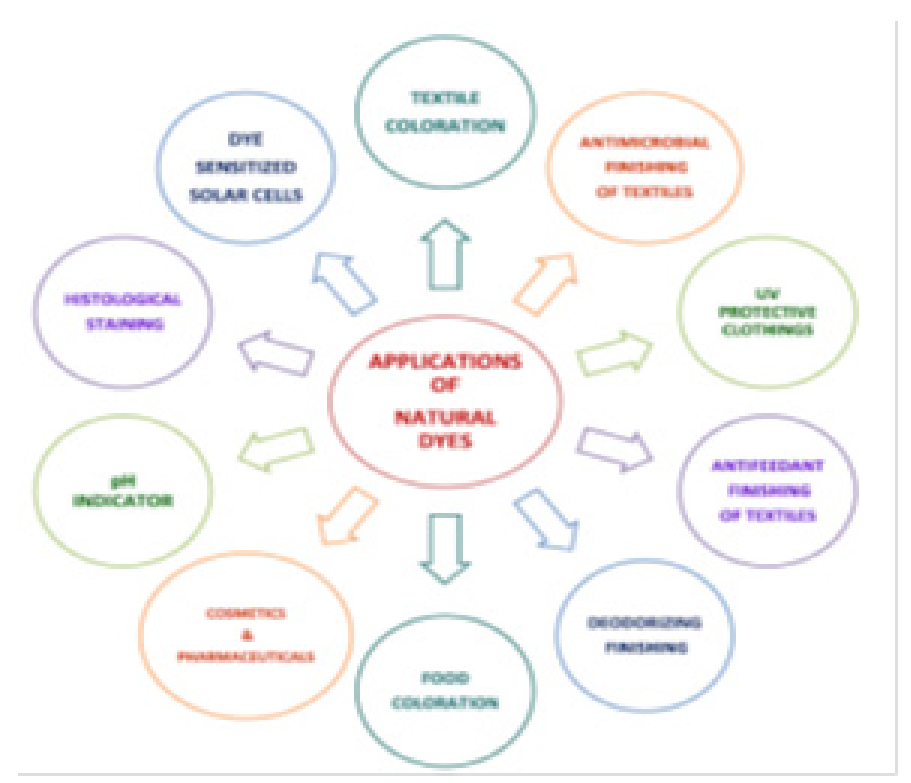

Fig. 1. Different uses of natural colourants.

New techniques for natural dyes' extraction for textile colouration:

State of arts procedure such as ultrasound, enzymatic technique and enzyme intermediate, ultrasonic extraction techniques are these days broadly being investigated for their high effectiveness over the traditional techniques.

\section{Enzymatic extraction technique:}

As plant tissues include cellulose, starches, and pectins as binding substances, economically accessible enzymes such as; cellulase, amylase, and pectinase have been utilized by a few specialists to release the surrounded material prompting to the extraction of colourant particles in reasonable terms. This procedure might be useful in the extraction of colourant from hard plant substances such as bark, roots, and so forth. M. B. Kasiri et al. [20] reported that a formula for enzymatic extraction method, a liquor ( $2 \%$ conc.) of cellulase: pectinase (1:2) was splashed on pomegranate skin (25 g) for good immersing. Then, left all the night long. The enzymatic treated substrate had been washed using small quantity of refined water and $\mathrm{pH}$ of the liquor was set to 10 . Then the treated fabrics were dyed at $140 \mathrm{rpm}$ for $20-80 \mathrm{~min}$ at required heating degree. All the contents of the beaker were separated using standard test sifter to eliminate hard substances and the colourant liquor had been concentrated using rotational vacuum evaporator till all the liquor is evaporated and the concentrated fluid was dried using spray-drier [21].

Sindra L Summoogum-Utchanah et al. [22] reported that MAE is an efficient process for the

J. Text. Color. Polym. Sci. Vol. 17, No.2 (2020) isolation of dyes from the studied biomass as it reduces the extraction time drastically compared to the classical system. The variation of solvent mixture, agitation speed of magnetic stirrer, microwave power, solid to solvent ratio and particle size of the plant were studied to determine the highest extraction yield of betalains and curcuminoids. The analysis revealed that the optimum conditions were obtained at $50 \%$ aqueous ethanol, agitation speed of $160 \mathrm{rpm}$, microwave power of $320 \mathrm{~W}$, particle size of $0.45 \mathrm{~mm}$ and a SSR of $1 / 35$. Besides, Peleg's and Elovich's mathematical models were evaluated to understand and describe the kinetics of natural dyes extraction. Peleg's kinetic model was mostly valid in describing the extraction kinetics particularly to MS while Elovich kinetic model fitted the experimental data of MAE more accurately. It could be ultimately deduced that the use of MAE for the leaching of pigmented solutes, is considered as a viable technique for enhancing a slow process and most essentially requiring fewer energy consumption, with high extract quality.

Enzyme assisted extraction and textile colouration [23]

Diverse sorts of enzymes are generally utilized as a part of different phases of material handling for alteration of chemical and physical surface properties or introducing functional groups on the surface of material strands $[24,25]$. A wide range of methodologies have been taken to the preparations, colouration and finishing processes of cotton [26], wool [27], silk [28, 29] and other material filaments [30] with natural dyes utilizing diverse sorts of enzymes [31]. They have revealed that enzymatic treatment brought about 
enhancement in colourant uptake in all cases, and credited it to improve shrink-resistance properties of the treated filaments. Kumbasar et al. [32] examined impacts of alkali proteases on colouring features of different proteinous substances with hydrolysable tannin based natural colourants got from sumac, myrobalan fruit, oak bark and gallnut detailed important increment in colourant uptake after treatment with enzyme. Wool fabrics treated with protease [33] and laccase [27] and coloured with madder have indicated higher water drop retention, bring down felting shrinkage, decreased fabric weight and decreased values of $a^{*}, b^{*}$ and $\mathrm{L}^{*}$ without any alteration in fastness properties of coloured fabrics. Vankar and co-authors examined the impact of 3 enzymes; lipase, diasterase, proteaseeamylase on colouring attributes of Terminalia arjuna, Punica granatum, Rheum emodi [28], Acacia catechu, Tectona grandis and Delonix regia $[34,35]$ on various sorts of textile fabrics. The scientists noticed that treatment with enzyme afford fast colour adsorption energy and aggregate higher adsorption than untreated fabrics in every one of the cases. The CIELab values also specified enhancement by treatment of enzyme. They demonstrated that colourant enzyme compatibility is an essential issue in improving colouring properties: protease- $\alpha$-amylase mixture is suitable for Acacia and Terminalia; lipase is suitable for Rheum and Delonix, however diasterase is suitable for Tectona and Punica. In comparison to untreated wool, the treatment of wool with protease and transglutaminase improved K/S values of wool coloured with sappan colourant; but, no major differences were noticed in fastness properties [36].

The most recent progress regarding improvements in enzymatic application procedures give conceivable outcomes for the advancement of new enzyme based natural colouration frameworks for a more environmental methodology in the textile manufacturing. Nevertheless, additional deeply study is required in regards colour enzyme compatibility for the selection of enzyme with a specific colourant for adopting enzyme assisted colouration technique on business scale.

Ultrasonic assisted extraction of natural colourants [37]

Ultrasonic is categorized by frequency range as power ultrasound $(20-100 \mathrm{kHz})$ and diagnostic ultrasound $(1-10 \mathrm{MHz})$. At the point when a fluid is irradiated by ultrasound, micro bubbles show up, grow and oscillate to a great degree rapidly and even collapse viciously if the acoustic pressure is sufficiently high. The event of these collapses almost a firm surface will produce micro-jets and stun waves. Also, in the fluid stage encompassing the particles, high micro-mixing will augment the heat and mass exchange and even the dissemination of species inside the pores of the firm [38, 39]. P.S. Vankar et al. announced [40] the assessment of the colouration possibilities of Melastoma malabathricum whose fruit pulp demonstrated high colourant substances. Colourant extraction was conducted by traditional and ultrasonic methods. The dyeability for the aqueous extract of melastoma was assessed for colouration of cotton fabrics using 2 procedures; ultrasonic and traditional methods. The reason for utilizing ultrasonic was for growing up the colourant absorption, enhanced colourant adherence, and great colourfastness. The prevalence of sonicator colouration over traditional colouration regarding improved asset profitability and thus decreased squanders. It can be concluded that the procedure developed for natural colouration of cotton fabrics with fruit pulp of Melastoma malabathricum using ultrasonic in combination with metal salts (mordants) has shown marked enhancement for the colourant adherence and colourfastness features and could be suggested for manufacturing. Fig.2 displays a schematic diagram representing the cavitation phenomenon.
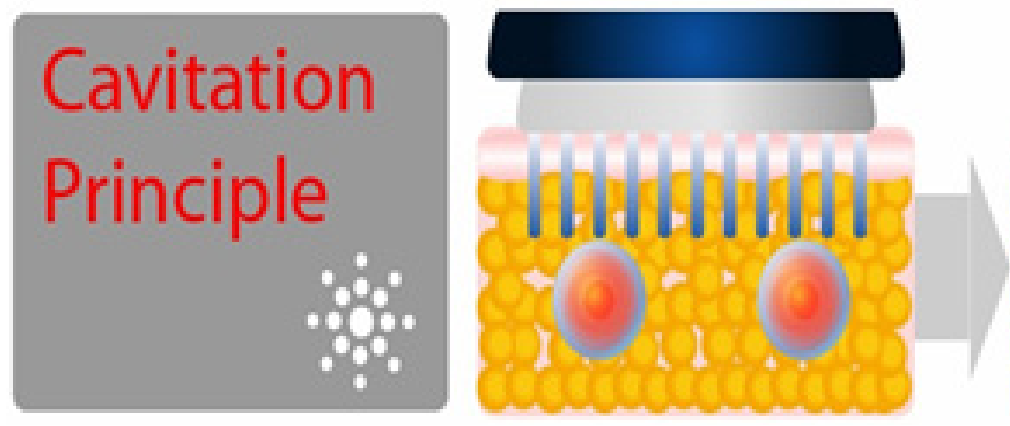

Fig. 2. Cavitation phenomenon.

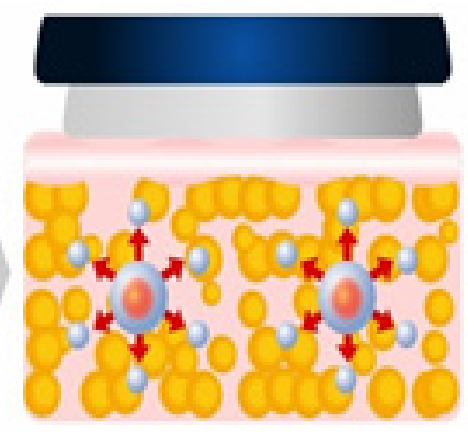


Ultrasonic assisted colouration with natural colourants [23]

In the most recent couple of years a specific number of studies on ultrasound assisted natural colouration and finishing of natural and synthetic fibres were conducted at the experimental level. Ultrasonic energy gave simple productive course for colourant extraction, mordanting, and colouration procedures comparing to the conventional methods [41]. Kamel et al. [42-45] comparatively studied different parameters for colouration of wool and cotton using ultrasonic in addition to traditional heat technique and announced that ultrasonic power substantially improved these colourants (lac, cochineal and saffron) extraction and coloration capability of fabrics comparing to traditional heat method due to ultrasonic cavitation affect. Vankar and coworkers studied the effect of ultrasonic technique for colouration of various types of different fabrics which are commercially accessible natural colourants such as catechu, tectona [34], madder [46] and identification, extracting and the application of natural colourants from new plant resources such as Ixora coccinea [47], Eclipta alba [48], Symplocos spicata, Acer pectinatum [26], Mahonia napaulensis [49], Delonix regia [35], Daphne papyraceae [29], Melastoma malabathricum [40]. Xinsheng et al. [50] announced the merits of ultrasonic extraction of colourant from Sargentodoxa cuneata and its application on wool fabrics.

The utilization of ultrasound energy in dyeing of wool fabrics in presence of glucose/ hydrogen peroxide based redox system in presence of alum as a mordant [51] and silk fabrics using mild mordants [41] is found to have a important enhancement in colourant uptake representing sonication effectiveness in textile colouration. Sivakumar et al. [37, 52] discussed the extraction of colourants from some dye yielding plants such as beetroots, Green wattle barks, Marigold flowers, Pomegranate rinds, 4'O clock plant flowers and Cocks comb flowers and announced important enhancement in extraction effectiveness of the colourants due to the utilization of ultrasound. Guesmi et al. [53] announced substantial enhancement of about $49.62 \%$ more colourant uptake in case of sonicator colouration of modified acrylic fabrics with indicaxanthin natural colouration in addition to better light, washing and water fastness results than the traditional technique. J. Prakash Marana et al. [54] has announced the natural pigments from Bougainvillea glabra flowers were successfully extracted through an ultrasoundassisted extraction (UAE) procedure. The best conditions of the extracting parameters over the highest extracting yield of colourants were affirmed through BBD. The best parameters of the extracted natural pigments from Bougainvillea glabra flowers. The results showed that the pigments from Bougainvillea glabra flowers can be successfully extracted through UAE.

V. Sivakumar et al. [37] has announced that natural colourants give an ecologically harmless option for colouration of textiles. It was announced that using ultrasonic can increase the extraction of colourants from various parts of different plant assets. Hence five colourant yielding plants were considered namely Green, Marigold, Pomegranate, and Cocks Comb. Extraction was done utilizing ultrasonic as well as magnetic stir ring methods and the kinetics and the extraction effectiveness were compared. The explanation behind the enhancement might be because of better leaching of natural colourant material from plant cell membranes and mass transfer to solvent assisted by acoustic cavitation supplied by ultrasonic. The results show that there is about $12-100 \%$ enhancement in \% yield of extract gained due to the utilization of ultrasonic comparing to magnetic stirring at $45{ }^{\circ} \mathrm{C}$. One would expect better extraction effectiveness with solvents like n-hexane for those colourant materials better soluble in organic solvents. $\mathrm{N}$. A. Abdul Rahman et al. [55] exhibited ultrasonic cleaner as a method of colouring the colourant from a chosen plant, i.e Xylocarpus moluccensis to a chosen fabric, i.e silk. Colourant from mixture of heartwood and bark (as a biomordant) of Xylocarpus moluccensis was coloured at various ultrasonic volume and time. The results demonstrate the most elevated rate of colourant absorbed to silk fabric utilizing ultrasonic cleaner was created at ideal condition of medium sonic volume in about 80 minutes. Bark of Xylocarpus moluccensis was utilized as the bio-mordant to give good results of colour fastness properties to washing and perspiration. From those results, it can be concluded that utilization of ultrasonic cleaner and bio-mordant achieved important enhancement in the colouration of silk fabrics with natural colourants at lower dyeing temperature comparing to conventional roaches technique.

S.R. Shirsatha et al. [56] announced that colourants got from natural resources for these 
applications have developed as an significant alternate to possibly destructive synthetic colourants and posture required for appropriate efficient extraction procedures. There have been a few reports identified with the utilization of ultrasonic for the increase of extraction of natural colourants. Natural colourant from beetroot was extracted using ultrasonic energy and compared with the traditional technique based on stirring [52]. The utilization of ultrasonic was found to have important enhancement in the extraction effectiveness of colourant acquired from beetroot. Around $80 \%$ improvement in the yield of colourant was accomplished with ultrasonic, comparing to magnetic stirring procedure using 1:1 ethanol-water. The dyeing capability of extracted beet colourant was tested on different materials and observed to be appropriate for colouring. Cuoco et al. [57] examined UAE of madder (Rubia tinctorum) root colourants. Maximum yield of $64.3 \%$ was acquired utilizing ultrasound extraction for 18 min extraction time, $36{ }^{\circ} \mathrm{C}$ temperature, $37 \%$ methanol as solvent and $0.5 \mathrm{~mm}$ roots size. The normal reflux technique of extraction of madder roots colourants gave $58.3 \%$ yield in $60 \mathrm{~min}$.

Padma S. Vankar [48] has reported the colouration of cotton fabric utilizing Eclipta as natural colourant has been examined in both traditional and ultrasonic methods. The impacts of colouration show greater colour strength values got by the last mentioned. Colouring energy of cotton fabric was analyzed for both the techniques. The time/ colourant uptake discloses the improved colourant uptake demonstrating sonicator proficiency. Vrushali M. Kulkarn at al. [58] reported the mapping of ultrasonic bath and the optimum conditions of factors influencing ultrasonic assisted extraction of mangiferin from $\mathrm{M}$. indica leaves were effectively conducted. According to correlation of ultrasonic extracting using soxhlet apparatus, the results showed that the amount of colouring matter extract was around 54\% from ultrasonic extracting in just 4 min. Consequently, the investigation of studying different factors of ultrasonic bath conditions has been assisted by evading needless consuming of power, which thus will make the procedure more financially savvy. M.M. Kamel et al. [59] announced that ultrasound method granted the biggest impact for the extraction of Cochineal colourant and give greatest extraction amount at $300 \mathrm{~W}$ which is correlated with reducing the average molecule size. Better colour strength values are noticed for coloured cationized cotton fabrics utilizing ultrasonic method in comparison to the results acquired via the traditional method. The outcomes of $\mathrm{X}$ beam diffraction studies and SEM pictures gave visual proofs that the ultrasonic method is helpful in improving the fabric dyeability than the traditional colouration method as measured by K/S values and in improvement the fastness properties of the coloured fabrics. The natural colouring matter extracted from turmeric (Curcuma longa L.) is usually utilized for colouration of textiles and food products. Curcumin have got a biological effect in different fields. The ultrasonic extracting method is used for separation of curcumin from turmeric plant. Turmeric specimen has been extracted in an ultrasonic water bath $(35 \mathrm{kHz})$ and have a double jacket cell for keeping up the heating degree at $25^{\circ} \mathrm{C}$ for evading high heating caused by exposure to ultrasound waves [60]. S. Rouhani et al. announced the amount of ultrasonic extracting was around 3 times greater than conventional technique. Curcumin extracting expanded by expanding the extracting time, however, However, as the extracting time was higher than $15 \mathrm{~min}$, the extracting amount reduced with expanding the time showing that prompted cavitation can corrupt components during exposing to ultrasonic for a long period.

G. Actis Grande et al. [61] reported the effect of the liquid temperature on the performance of ultrasounds (US) in a dyeing process. The approach was both theoretical and experimental. In the theoretical part the simplified model of a single bubble implosion is used to demonstrate that the "maximum implosion pressure" calculated with the well known Rayleigh-Plesset equation for a single bubble can be correlated with the cavitation intensity experimentally measured with an Ultrasonic Energy Meter (by PPB Megasonics). In particular the model was used to study the influence of the fluid temperature on the cavitation intensity. The "relative" theoretical data calculated from the implosion pressure were satisfactorily correlated with the experimental ones and evidence a zone, between 50 and $60{ }^{\circ} \mathrm{C}$, were the cavitation intensity is almost constant and still sufficiently high. Hence an experimental part of wool dyeing was carried out both to validate the previous results and to verify the dyeing quality at low temperatures $\left(40-70{ }^{\circ} \mathrm{C}\right)$ in presence of US. A prototype dyeing equipment able to treat textile samples with US system of $600 \mathrm{~W}$ power, was used. The dyeing performances in the presence and absence of US were verified by measuring DE (colour variation), Re,\% (reflectance percentage), $\mathrm{K} / \mathrm{S}$ (colour strength) and colour fastness. The US tests performed in the temperature range of $40-70{ }^{\circ} \mathrm{C}$ were compared with the conventional wool dyeing at $98^{\circ} \mathrm{C}$. The obtained results show that a temperature J. Text. Color. Polym. Sci. Vol. 17, No.2 (2020) 
close to $60^{\circ} \mathrm{C}$ should be chosen as the recommended US dyeing condition, being a compromise between the cavitation intensity and the kinetics which rules the dyestuff diffusion within the fibres. Ultrasonic can be successfully utilized to expand the yield and average of mass move in several solid-liquid extraction procedures [62]. The technique of intensification of extraction procedure has been credited to cavitation phenomena bringing about strong turbulence and fluid circulation streams in the framework [63-66]. The prior work on ultrasonic assisted extraction concentrated either regarding the experimental work on a particular framework or the impacts of utilization of ultrasonic in scientific strategies. The present work goes for giving an extensive examination of various viewpoints identified with intensification utilizing ultrasonic assisted extraction procedure and furthermore gives an overview of various applications linked to food, pharmaceuticals, perfumes, beauty care products and different manufactures. One of the novel contents of the current study is that the combinational extraction techniques in view of the utilization of ultrasonic have been highlighted which can additionally strengthen the procedure and bring about efficient processes even at commercial level processes. Additionally, the requirement for research work essential for development of big scale effective reactor have been highlighted in view of a point by point investigation of the current research identified with the ultrasonic assisted extraction which has not been highlighted in any of the prior work.

\section{Enzyme-ultrasonic assisted extraction}

Utilization of UAE and enzyme treatment for grape mash treatment has additionally been examined and it has been announced that consolidated ultrasound and enzyme treatment augmented extraction yield marginally, however reduced the time of treatment by more than 4 periods $[67,68]$. Ultrasonic enhances the transfer of enzyme macromolecules without producing extreme quantity of so responsive intermediates which may result in deactivation of enzyme. Additionally, ultrasound may likewise initiate the catalytic execution of the enzyme macromolecules adsorbed onto the outside of substrate and improve removal of the output of hydrolytic response from the response zone. Therefore ultrasound augmented the effectiveness of enzymatic curing with higher extraction yield and minimum curing time. WenJing Liu et al. reported that natural dye should be extracted before dyeing process. Currently the extract technology includes water extract, drying method, heating drying, ultrasonic, enzymatic, etc. The traditional extractions, such as water extract, heating drying method causes a certain environmental pollution and numerous energy consumption due to the organic solvent used in separation and purification for extraction process, so the clean extract technologies such as biological enzyme and ultrasonic method are most popular. Biological enzyme functions at the plant's material surface, destructs cell wall, reduces the resistance of extracting colourant from the cells, so as to improve the extract yield, with low temperature, high purity and less pollution character. Ultrasonic method is a broken method. Ultrasonic waves stay in plants cell longer and deeper than what an electromagnetic waves can penetrate, and the effective components of the plant can be extracted easily [69]. In recent years, there are many reports on extracting natural dyes by enzyme or ultrasonic method. Zhao YH extracted anthocyanin in indigo slag with cellulase and pectase by enzyme hydrolysis extraction method [70], it was found that the extract yield by adopting composite double enzyme hydrolysis was 3.05 and 1.53 times higher than cellulase and pectase used by itself respectively. Qiu B, et al. compared water extract and pectase by adding in the extract process of gardenia yellow [71], the conclusion was, the extract yield of gardenia yellow with the presence of pectase was higher than that of traditional extraction. finally it was confirmed that, ultrasonic extract method was much more excellent than traditional process. According to the researches above we can see, both enzyme and ultrasonic technology are able to increase the extract yield in the extracting process of natural plant dyestuff, but there is litter report on extracting natural dye by enzyme/ultrasonic technology. In order to increase the extract yield, we chose enzyme - ultrasonic method to extract cortex phellodendri and rubia and studied various factors in the extract process, which improves the extract efficiency and saves energy at the same time. Harish C Tiwari et al. [72] reported ultrasound, enzyme and enzyme-mediated ultrasound assisted extraction procedures have been utilized for the extraction of dye from pomegranate skin. Ideal factors for colourant extraction are observed at $\mathrm{pH} 10$, extraction time $40 \mathrm{~min}$ and temperature $50^{\circ} \mathrm{C}$. The yields for ultrasound, enzyme, enzymemediated ultrasound assisted and solvent extraction are observed at $29.2 \%, 26.5 \%, 35.6 \%$ and $8.8 \%$ correspondingly. The colourant acquired has been utilized for colouration of wool and cotton, maintaining the ideal colourant bath concentration at $10 \%$ and $8 \%(\mathrm{w} / \mathrm{v})$ correspondingly. The results of fastness features of wool are excellent while that of cotton is just adequate. Fig. 3 shows images of ultrasonic and microwave apparatuses. 


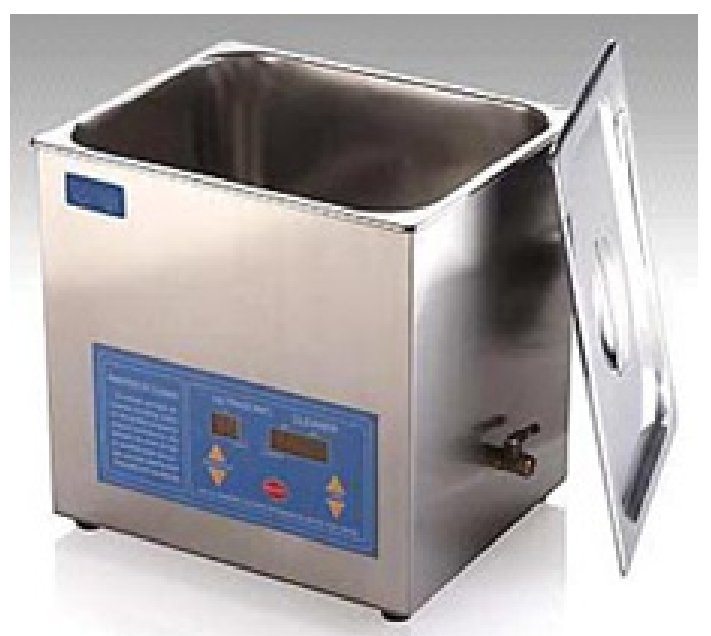

Ultrasonic water bath

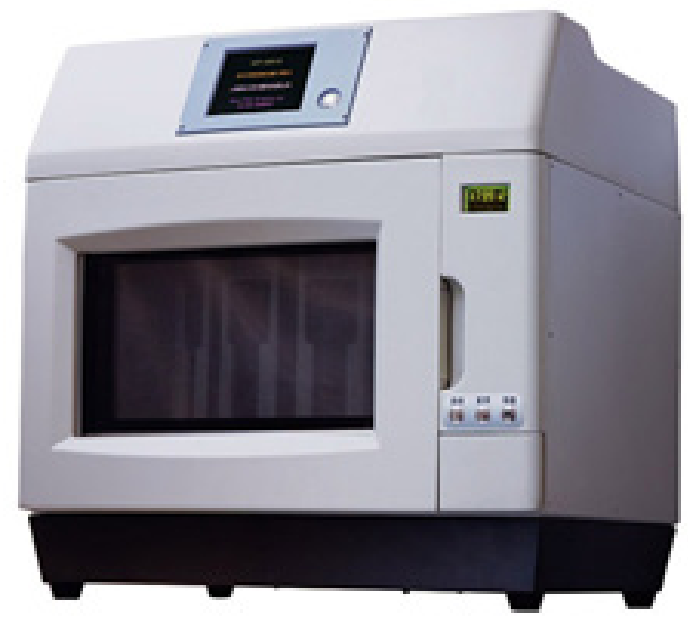

Microwave Extraction System

Fig. 3. Ultrasonic and Microwave apparatuses.

\section{Ultrasonic and microwave assisted extraction}

These are really microwave- and ultrasoundassisted extraction techniques where extraction effectiveness is augmented by the utilization of ultrasonic or microwave therefore decreasing the amount of needed solvent, time, and temperature of extraction. As, the natural colourant containing plant materials is treated with water or any other solvent and exposed to ultrasound, very little bubbles or cavitations are created in the fluid. However, bubbles are augmented in size and achieved a specific size, they can't hold their shape. At the point when this happens, the cavity breakdowns or the bubbles burst making high temperature and pressure. A huge number of these bubbles are created and collapse each second. The production of high temperature and pressure during extraction process augments the extraction effectiveness in a short time. Likewise the procedure can be completed at lower temperature and thus extraction of heat-sensitive colourant materials is better. As investigation of new colourant sources and efforts to optimize the colourant extraction procedures are proceeding with, utilization of this extraction method has been lately revealed by numerous scientists [73-77]. Productivity of a colourant extraction procedure relies on its selectivity, rate, yield, reproducibility, and protection of extracted compounds against compound change [78]. Pasquet et al. [79] have examined microalgal colourant extraction from Dunaliella tertiolecta (chlorophyte) and Cylindrotheca closterium (bacillariophyte) by utilizing microwave assisted extraction (MAE) and its performance was contrasted with traditional procedures (cold and hot soaking) and ultrasonic- assisted extraction. In microwave extraction, the natural resources are treated with a small quantity of solvent within the sight of microwave energy resources. Microwave augments the rate of the procedures so the extraction can be finished in a smaller time with better yield. Sinha et al. [80] have detailed extraction of annatto colourant with microwave energy. Previously, their group had announced microwave-assisted extraction of blue colourant from the butterfly pea [81]. Microwave and ultrasound extraction may be considered as environmentally-friendly procedures because of diminishment of extraction temperature, solvent utilization, and time which brings about lower utilization of power.

\section{Conclusion}

Environmental concerns grow up due to accelerated progress in textile wet processing manufacture paved the way for ongoing interest in the progress of green production strategies for making cost-effective value added textile products. There has also been remarkable improvement in extraction techniques of natural colourants such as the invention of ultrasound or microwave assisted extraction techniques where they prove high extraction efficiency over the traditional techniques. The utilization of enzymes in extraction of natural colourants is an example of industrial biotechnology, which allows the progress of environmentally- friendly technologies in fibre processing and strategies to enhance the quality of final product. It has revealed that enzymatic treatment brought about enhancement in colourant uptake in all cases, and credited it to improve shrink-resistance properties of the treated fibers. 


\section{References}

1. Ahmed, H.E., et al., Identification of natural dyes in rare Coptic textile using HPLC-DAD and mass spectroscopy in museum of Faculty of Arts, Alexandria University, Egypt. Dyes and Pigments, 145, p. 486-492 (2017).

2. Ford, L., C.M. Rayner, and R.S. Blackburn, Degradation of lucidin: New insights into the fate of this natural pigment present in Dyer's madder (Rubia tinctorum L.) during the extraction of textile artefacts. Dyes and Pigments, 154, p. 290-295 (2018).

3. Zerin, I., et al., Potentials of Natural Dyes for Textile Applications, in Encyclopedia of Renewable and Sustainable Materials, S. Hashmi and I.A. Choudhury, Editors. Elsevier: Oxford. p. 873-883 (2020).

4. Saxena, S. and A.S.M. Raja, Natural Dyes: Sources, Chemistry, Application and Sustainability Issues, in Roadmap to Sustainable Textiles and Clothing: Eco-friendly Raw Materials, Technologies, and Processing Methods, S.S. Muthu, Editor. Springer Singapore: Singapore. p. 37-80 (2014).

5. Gawish SM, et al., Eco-Friendly Multifunctional Properties of Cochineal and Weld for Simultaneous Dyeing and Finishing of Proteinic Fabrics. International Journal of Engineering and Technology, 8(5), p. 2246- 2253 (2016).

6. K, A., G.A. S, and S. N, Dyeing of textiles with natural dyes extracted from Terminalia arjuna and Thespesia populnea fruits. Industrial Crops and Products, 148, p. 112303 (2020).

7. de Ferri, L., et al., Non-invasive study of natural dyes on historical textiles from the collection of Michelangelo Guggenheim. Spectrochimica Acta Part A: Molecular and Biomolecular Spectroscopy, 204, p. 548-567 (2018).

8. Helmy H.M., et al., Impacts of Air Pollution on Colour Fading and Physical Properties of Wool Yarns Dyed with Some Natural Dyes in Residential Site. J Textile Sci Eng, 5(6), p. 1-8 (2015).

9. Maynez-Rojas, M.A., E. Casanova-González, and J.L. Ruvalcaba-Sil, Identification of natural red and purple dyes on textiles by Fiber-optics Reflectance Spectroscopy. Spectrochimica Acta Part A: Molecular and Biomolecular Spectroscopy, 178, p. 239250 (2017).

10. Bhuiyan, M.A.R., et al., Color and chemical constitution of natural dye henna (Lawsonia inermis L) and its application in the coloration of textiles. Journal of Cleaner Production, 167, p. 14-22 (2017).

J. Text. Color. Polym. Sci. Vol. 17, No.2 (2020)
11. Silva, P.M.d.S., et al., Natural dye from Croton urucurana Baill. bark: Extraction, physicochemical characterization, textile dyeing and color fastness properties. Dyes and Pigments, 173, p. 107953 (2020).

12. Gawish SM, et al., UV Protection Properties of Cotton, Wool, Silk and Nylon Fabrics Dyed with Red Onion Peel, Madder and Chamomile Extracts. Journal of Textile Science \& Engineering 6(4), p. $1-13$ (2016).

13. Gawish SM , et al., Effect of Mordant on UV Protection and Antimicrobial Activity of Cotton, Wool, Silk and Nylon Fabrics Dyed with Some Natural Dyes. Journal of Nanomedicine \& Nanotechnology 8(1), p. 1-9 (2017).

14. Fröse, A., et al., Application of natural dyes on diverse textile materials. Optik, 181, p. 215-219 (2019).

15. Chakraborty, L., P. Pandit, and S. Roy Maulik, Acacia auriculiformis - A natural dye used for simultaneous coloration and functional finishing on textiles. Journal of Cleaner Production, 245,p. 118921 (2020).

16. Błyskal, B., Gymnoascus arxii's potential in deteriorating woollen textiles dyed with natural and synthetic dyes. International Biodeterioration \& Biodegradation, 86, p. 349-357 (2014).

17. Adeel, S., et al., Appraisal of marigold flower based lutein as natural colourant for textile dyeing under the influence of gamma radiations. Radiation Physics and Chemistry, 130, p. 35-39 (2017).

18. Baliarsingh, S., et al., Role of cationic and anionic surfactants in textile dyeing with natural dyes extracted from waste plant materials and their potential antimicrobial properties. Industrial Crops and Products, 50, p. 618-624 (2013).

19. Haji, A. and M. Naebe, Cleaner dyeing of textiles using plasma treatment and natural dyes: A review. Journal of Cleaner Production, 265, p. 121866. (2020).

20. Kasiri, M.B. and S. Safapour, Natural Dyes and Antimicrobials for Textiles Lichtfouse E. , Schwarzbauer J. , and Robert D. , Editors. Springer Dordrecht Heidelberg: New York. p. 229-281 (2013).

21. Tiwari, H., et al., Evaluation of various techniques for extraction of natural colorants from pomegranate rind -ultrasound and enzyme assisted extraction. Indian J Fibre Text Res 35(3), p. 272-276 (2010). 
22. Sindra, L.S.-U. and J. Hashita, An investigation on the potential of extracting natural dyes from beetroot and turmeric. International Journal of Research in Engineering and Technology, 4(2), p. 401- 416 (2015).

23. Shahid, M., I. Shahid ul, and F. Mohammad, Recent advancements in natural dye applications: a review. Journal of Cleaner Production, 53, p. 310331 (2013).

24. Duran, N. and M. Duran, Enzyme applications in the textile industry. Review of Progress in Coloration and Related Topics, 30(1), p. 41-44 (2000).

25. Araújo, R., M. Casal, and A. Cavaco-Paulo, Application of enzymes for textile fibres processing. Biocatalysis and Biotransformation, 26(5), p. 332-349 (2008).

26. Vankar, P.S., et al., Sonicator dyeing of natural polymers with Symplocos spicata by metal chelation. Fibers and Polymers, 9(2), p. 121 (2008).

27. Montazer, M., et al., Treatment of Wool with Laccase and Dyeing with Madder. Applied Biochemistry and Biotechnology, 158(3), p. 685-693 (2009).

28. Vankar, P.S., R. Shanker, and A. Verma, Enzymatic natural dyeing of cotton and silk fabrics without metal mordants. Journal of Cleaner Production, 15(15), p. 1441-1450 (2007).

29. Vankar, P.S., et al., Chemical characterisation of extract derived from Daphne papyraceae and sonicator dyeing of cotton, silk and wool with the extract. Pigment \& Resin Technology, 38(3), p. 181187 (2009).

30. Sricharussin, W., et al., Effect of enzymatic treatment on the dyeing of pineapple leaf fibres with natural dyes. Science Asia, 35(1), p. 31-36 (2009).

31. Salem, M.Z.M., et al., Assessment of the Use of Natural Extracted Dyes and Pancreatin Enzyme for Dyeing of Four Natural Textiles: HPLC Analysis of Phytochemicals. Processes, 8(1), p. 59 (2020).

32. Kumbasar, E.P.A., R. Atav, and M.I. Bahtiyari, Effects of Alkali Proteases on Dyeing Properties of Various Proteinous Materials with Natural Dyes. Textile Research Journal, 79(6), p. 517-525 (2009).

33. Parvinzadeh, M., Effect of proteolytic enzyme on dyeing of wool with madder. Enzyme and Microbial Technology, 40(7), p. 1719-1722 (2007).

34. Vankar, P.S. and R. Shanker, Ecofriendly ultrasonic natural dyeing of cotton fabric with enzyme pretreatments. Desalination, 230(1-3), p. 62-69 (2008).
35. Vankar, P.S. and R. Shanker, Eco-friendly pretreatment of silk fabric for dyeing with Delonix regia extract. Coloration Technology, 125(3), p. 155-160 (2009).

36. Zhang, R.-p. and Z.-s. Cai, Study on the natural dyeing of wool modified with enzyme. Fibers and Polymers, 12(4), p. 478-483 (2011).

37. Sivakumar, V., J. Vijaeeswarri, and J.L. Anna, Effective natural dye extraction from different plant materials using ultrasound. Industrial Crops and Products, 33(1), p. 116-122 (2011).

38. Contamine, F., et al., Chemical reactions under ultrasound: discrimination of chemical and physical effects. Chemical Engineering Science, 49(24), p. 5865-5873 (1994).

39. Guinot, P., et al., Serratula tinctoria, a source of natural dye: Flavonoid pattern and histolocalization. Industrial Crops and Products, 29(2-3), p. 320-325 (2009).

40. Vankar, P.S., et al., Sonicator dyeing of cotton fabric and chemical characterization of the colorant from Melastoma malabathricum. Pigment \& Resin Technology, 38(1), p. 38-42 (2009).

41. Mansour, H.F. and S. Heffernan, Environmental aspects on dyeing silk fabric with sticta coronata lichen using ultrasonic energy and mild mordants. Clean Technologies and Environmental Policy, 13(1), p. 207-213 (2011).

42. Kamel, M.M., et al., Ultrasonic assisted dyeing: III. Dyeing of wool with lac as a natural dye. Dyes and Pigments, 65(2), p. 103-110 (2005).

43. Kamel, M.M., et al., Ultrasonic assisted dyeing. IV. Dyeing of cationised cotton with lac natural dye. Dyes and Pigments, 73(3), p. 279-284 (2007).

44. Kamel, M.M., et al., Ultrasonic dyeing of cationized cotton fabric with natural dye. Part 1: Cationization of cotton using Solfix E. Ultrasonics Sonochemistry, 16(2),p. 243-249 (2009).

45. Kamel, M., H. Helmy, and N. El Hawary, Some studies on dyeing properties of cotton fabrics with crocus sativus (Saffron flowers) using an ultrasonic method. Journal of Natural Fibers, 6(2), p. 151-170 (2009).

46. Vankar, P.S., et al., Ecofriendly sonicator dyeing of cotton with Rubia cordifolia Linn. using biomordant. Dyes and Pigments, 76(1), p. 207-212 (2008).

47. Vankar, P.S. and R. Shanker, Sonicator dyeing of cotton and silk fabric by Ixora coccinea. Asian Text., 15(2), p. 77-80 (2006).

J. Text. Color. Polym. Sci. Vol. 17, No.2 (2020) 
48. Vankar, P.S., R. Shanker, and J. Srivastava, Ultrasonic dyeing of cotton fabric with aqueous extract of Eclipta alba. Dyes and Pigments, 72(1), p. 33-37 (2007).

49. Vankar, P.S., et al., Sonicator dyeing of modified cotton, wool and silk with Mahonia napaulensis DC. and identification of the colorant in Mahonia. Industrial Crops and Products, 27(3), p. 371-379 (2008).

50. Xinsheng, X., et al., Extraction of coloring matter from Sargentodoxa cuneata by ultrasonic technique and its application on wool fabric. Indian Journal of Fibre \& Textile Research 33(4), p. 426-430 (2008).

51. Mansour, H.F., Environment and energy efficient dyeing of woollen fabric with sticta coronata. Clean Technologies and Environmental Policy, 12(5), p. 571-578 (2010).

52. Sivakumar, V., et al., Ultrasound assisted enhancement in natural dye extraction from beetroot for industrial applications and natural dyeing of leather. Ultrasonics Sonochemistry, 16(6), p. 782-789 (2009).

53. Guesmi, A., et al., Sonicator dyeing of modified acrylic fabrics with indicaxanthin natural dye. Industrial Crops and Products, 42, p. 63-69 (2013).

54. Maran, J.P., B. Priya, and C.V. Nivetha, Optimization of ultrasound-assisted extraction of natural pigments from Bougainvillea glabra flowers. Industrial Crops and Products, 63, p. 182-189 (2015).

55. Abdul Rahman, N.A., R. Tajuddin, and S.M. Tumin, Optimization of Natural Dyeing Using Ultrasonic Method and Biomordant. International Journal of Chemical Engineering and Applications 4(3), p. 161-164 (2013).

56. Shirsath, S.R., S.H. Sonawane, and P.R. Gogate, Intensification of extraction of natural products using ultrasonic irradiations - A review of current status. Chemical Engineering and Processing: Process Intensification, 53, p. 10-23 (2012).

57. Cuoco, G., et al., A multivariate study of the performance of an ultrasound-assisted madder dyes extraction and characterization by liquid chromatography-photodiode array detection. Ultrasonics Sonochemistry, 16(1), p. 75-82 (2009).

58. Kulkarni, V.M. and V.K. Rathod, Mapping of an ultrasonic bath for ultrasound assisted extraction of mangiferin from Mangifera indica leaves. Ultrasonics Sonochemistry, 21(2), p. 606-611 (2014).

59. Kamel, M.M., et al., Ultrasonic dyeing of cationized cotton fabric with natural dye. Part 2: Cation- ization of cotton using Quat 188. Industrial Crops and Products, 34(3), p. 1410-1417 (2011).

60. Rouhani, S., et al., Ultrasonic Assisted Extraction of Natural Pigments from Rhizomes of Curcuma Longa L. Prog. Color Colorants Coat., 2, p. 103113 (2009).

61. Actis Grande, G., et al., Use of the ultrasonic cavitation in wool dyeing process: Effect of the dyebath temperature. Ultrasonics Sonochemistry, 35, Part A: p. 276-284 (2017).

62. Ashokkumar, M. and T.J. Mason, Sonochemistry, in Kirk-Othmer Encyclopedia of Chemical Technology. John Wiley \& Sons, Inc (2000).

63. Jadhav, D., et al., Extraction of vanillin from vanilla pods: A comparison study of conventional soxhlet and ultrasound assisted extraction. Journal of Food Engineering, 93(4), p. 421-426 (2009).

64. Ebringerová, A. and Z. Hromádková, An overview on the application of ultrasound in extraction, separation and purification of plant polysaccharides. Central European Journal of Chemistry, 8(2), p. 243-257 (2010).

65. Gogate, P.R. and A.B. Pandit, Sonochemical reactors: scale up aspects. Ultrasonics Sonochemistry, 11(3-4), p. 105-117 (2004).

66. Riera, E., et al., Mass transfer enhancement in supercritical fluids extraction by means of power ultrasound. Ultrasonics Sonochemistry, 11 (3- 4),p. 241-244 (2004).

67. Wen-Jing, L., et al., Study on Extracting Natural Plant Dyestuff by Enzyme-ultrasonic Method and its Dyeing Ability. Journal of Fiber Bioengineering and Informatics, 2(1), p. 25-30 (2009).

68. Lieu, L.N. and V.V.M. Le, Application of ultrasound in grape mash treatment in juice processing. Ultrasonics Sonochemistry, 17(1), p. 273-279 (2010).

69. Zhao, Y., Y. Miao, and L. Zhao, Studies on extracted anthocyaninsn in indigo slag with cellulase and pectic enzymes by enzyme hydrolysis extraction method. J. Chinese Food, 8(4), p. $75-79$ (2008).

70. YH, Z., Extract technology of natural products. Vol. 6. China: Chinese Light Technology Press (2006).

71. Qiu, B., W. Chen, and Q. Wang, Comparer of water extract and pectase adding in the extract process of gardenia yellow. Food Industry 1, p. 29-31 (2008). 
72. Harish, C.T., et al., Evaluation of various techniques for extraction of natural colorants from pomegranate rind-Ultrasound and enzyme assisted extraction. Indian Journal of Fibre \& Textile Research, 35(9), p. 272- 276 (2010)

73. Liu;, W.-J., et al., Study on Extracting Natural Plant Dyestuff by Enzyme-ultrasonic Method and its Dyeing Ability. Journal of Fiber Bioengineering and Informatics, 2(1), p. 25-30 (2009).

74. Mishra, P., et al., Extraction of natural dye from Dahlia variabilis using ultrasound. Ind J Fib Text Res 37(1), p. 83-86 (2012).

75. Pradeep KM, et al., Extraction of natural dye from Dahlia variabilis using ultrasound. Ind J Fib Text Res 12, p. 83-86 (2012).

76. Rahman;, N.A.A., S.M. Tumin;, and R. Tajuddin;, Optimization of Ultrasonic Extraction Method of Natural Dyes from Xylocarpus Moluccensis. International Journal of Bioscience, Biochemistry and Bioinformatics, 3(1), p. 53-55 (2013).

77. Helmy, H.M., et al., Antimicrobial Activity of Dyed Wool Fabrics with Peanut Red Skin Extract Using Different Heating Techniques. Egyptian Journal of Chemistry, 2017. 60(Conference Issue (The 8th International Conference of The Textile Research Division (ICTRD 2017), National Research Centre, Cairo 12622, Egypt.)): p. 103-116.

78. Helmy H. M., et al., The Environmentally Benign Extraction of Peanut Red Skin for Textile Coloration and its UV Protection Properties. International Journal of Pharmaceutical Sciences Review and Research, 47(1), p. 1-12 (2017).

79. Pasquet, V., et al., Study on the microalgal pigments extraction process: Performance of microwave assisted extraction. Process Biochemistry, 46(1), p. 59-67 (2011).

80. Sinha, K., et al., Modeling of microwave-assisted extraction of natural dye from seeds of Bixa orellana (Annatto) using response surface methodology (RSM) and artificial neural network (ANN). Industrial Crops and Products, 41, p. 165-171 (2013).

81. Sinha, K., et al., Improved extraction of natural blue dye from butterfly pea using microwave assisted methodology to reduce the effect of synthetic blue dye. Int J Chem Tech 4(2), p. 57-65 (2002). 


\section{طرق استخراج الأصباغ الطبيعية لتلوين النسيج}

شعبة بحوث الصني ماعات النسيجية ـ المركز القومي للبحوث ـ القاهرة ـ مصر.

تقنيات جديدة لاستخر اج الأصباغ الطبيعية مثل استخر اج الموجات فوق الصوتية ، واستخراج الميكروويف

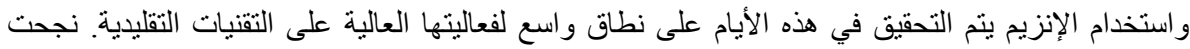

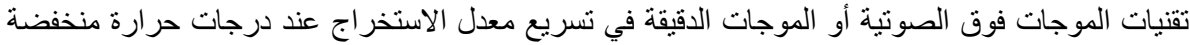

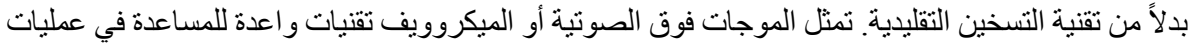

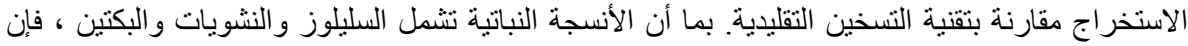

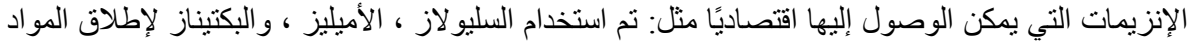

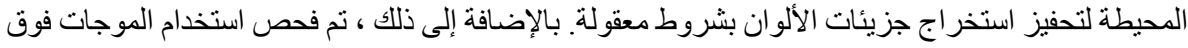

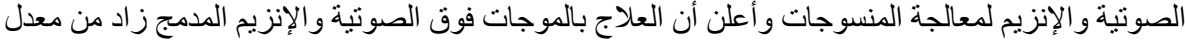

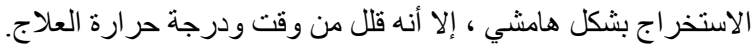

